\title{
Filosofia do cuidado e vulnerabilidade
}

\section{The Philosophy of Care and Vulnerability}

DOI: 10.12957/ek.2021.56723

\author{
Paulo Ricardo Martines ${ }^{1}$ \\ Universidade Estadual de Maringá \\ prmartines@uem.br \\ http://orcid.org/0000-0001-6396-696X
}

\section{RESUMO}

A pandemia do coronavírus trouxe à tona uma crise de saúde pública e econômica de nível mundial sem precedentes, que, em nosso país, aprofundou a desigualdade social e acentuou a vulnerabilidade dos grupos mais pobres. Alguns países agiram prontamente logo no início do ciclo pandêmico e conseguiram minimizar suas consequências, como a Coreia do Sul ou a Alemanha; outros sofreram bastante com os números elevados de contaminados e de óbitos, como a Espanha e a Itália. Mas nada igual àquilo que se verificou nos EUA e Brasil, cujos presidentes ignoraram e minoraram o contágio, desautorizando o discurso científico e pouco agindo na esfera pública para resistir à pandemia. A crise brasileira vai de par com o desmonte das instituições públicas, quer ligadas à saúde, quer à ciência ou à educação. O objetivo deste artigo é considerar a noção filosófica de cuidado como uma tentativa de resposta efetiva à situação pela qual passamos, a fim de estabelecer um horizonte que amplie a nossa visão e nos permita ver além do que está próximo, não para afastar o olhar, mas para ver melhor. A noção filosófica de cuidado, tal como a entendo, é devedora tanto da reflexão de Hans Jonas sobre a responsabilidade, enquanto expressão de um compromisso autêntico com a dignidade da vida humana, como da reflexão de Paul Ricoeur

1 Doutor em Filosofia pela Universidade Estadual de Campinas. Atua como professor adjunto na Universidade Estadual de Maringá. 
sobre a noção de sabedoria prática, demarcada pela solicitude enquanto uma preocupação com o outro.

Palavras-chave: Ética. Responsabilidade. Solicitude. Cuidado.

\begin{abstract}
The Covid-19 pandemic brought to the surface a novel crisis in public health and economy worldwide. Social inequality revealed itself more profoundly in Brazil and deepened the vulnerability of society's poorest members. Several countries, such as South Korea and Germany reacted almost immediately at the start of the pandemic cycle and succeeded in minimizing its consequences, whilst others, such as Italy and Spain, suffered immensely due to high numbers of infected people and deaths. However, what happened in the USA and in Brazil has still to be equaled. The presidents of the last two countries ignored and downgraded the contagion, discarded scientific discourse and failed to act within the public sphere to combat the disease. The crisis in Brazil has been accompanied by the undoing of public institutions linked to health, science and education. Current paper analyzes the philosophic concept of care for an effective response to the situation described above and establishes a wider perspective that would permit us perceive beyond what is close. This does not make us shun the gaze but makes us see better. The philosophical concept of care is foregrounded on discussions by Hans Jonas on responsibility and on Paul Ricoeur idea of practical wisdom based on solicitude as concern for the other.
\end{abstract}

Keywords: Ethics. Responsibility. Solicitude. Care.

Que o de que vive o mundo são mudanças Mudai, pois, o sentido e o cuidado.

Camões

Esta água que do alto cai acordar-me-ia Do sono não, mas de cuidados graves.

Sá de Miranda 


\section{INTRODUÇÃO: UMA POSSÍVEL RESPOSTA À PANDEMIA}

A noção de cuidado revela, de um modo geral, a atitude de proteção que temos diante de algo ou alguém, como manifestação de nossa responsabilidade e solicitude. De um ponto de vista particular, designa o estado de espírito de alguém absorvido por algo que lhe causa preocupação e inquietação, e que o impulsiona a agir diante das dificuldades ou perigos. Nos dias atuais, a crise derivada da pandemia do coronavírus reacendeu para alguns o cuidado que devemos ter conosco, com os outros e com a natureza, e, ao mesmo tempo, manifestou a vulnerabilidade da vida humana, exigindo de nós uma resposta precisa diante desse estado de coisas. Já se disse que a pandemia atual está diretamente associada com as questões ambientais, especialmente com as mudanças climáticas relacionadas com o aumento da temperatura (algo que implica a alteração da condição e padrão dos vírus e bactérias), com o desflorestamento e com o degelo, motivos que elevam os riscos dos patógenos vindo dos animais silvestres. Tais alterações aumentam a vulnerabilidade humana. Essa preocupação se torna urgente, diante do quadro político nacional atual de completa desorganização institucional, na qual entidades públicas são desmanteladas e desfiguradas em sua estrutura básica. Casos expressivos foram vistos no Ministério da Saúde, que ficou sem titular por quase dois meses, ao longo do ano de 2020, ou do desmonte perpetrado no Ministério do Meio Ambiente, que, no caso específico das populações indígenas, não realizou nenhuma ação sistemática e articulada com o Ministério da Saúde, na proteção da saúde indígena, o que gerou grande impacto na contaminação dessas comunidades.

O governo federal, durante a pandemia, elevou o "caos" como método de ação (NOBRE, 2020, p. 25). A resposta do governo é em favor da economia, da abertura comercial e da atividade econômica, embora isso possa oferecer risco de morte para muitos, entenda-se, para os mais pobres e vulneráveis, uma vez que o declínio da economia (nessa lógica) seria muito mais catastrófico para todos. Duas outras "razões" estão atreladas a esse tipo de discurso: primeira, aquela segundo a qual a epidemia não é tão grave o quanto indicam certos discursos médicos que circulam pelas mídias, pois possui um nível de letalidade baixo; segunda, a preocupação com a saúde (na sua versão medicalizante) não 
deve suplantar a liberdade e a autonomia dos sujeitos. ${ }^{2}$ Ambas as "razões" desqualificam e enfraquecem as medidas de confinamento. A esse quadro deve ser somado o discurso negacionista do presidente Bolsonaro. Os direitos humanos e a questão ambiental, decisivos para se pensar a defesa e a dignidade da vida, são alijados da política atual. Vivemos numa frágil e dissolvente democracia, sob o temor permanente da "influência dos ignorantes" (GALBRAITH, 1972, p.71), isto é, daqueles que são incapazes de entender um argumento alheio, ou que são pouco propensos a serem persuadidos, o que os leva na maioria das vezes a se valerem de um discurso beligerante.

Esse pensamento do governo federal parece exigir uma alternativa - ou a economia ou a preservação de vidas -, e a escolha em muitos níveis de decisão política parece ter sido pela primeira. Não penso que devemos fazer a escolha acima, porque ela é enganosa, mas precisamos garantir a defesa da vida em primeiro lugar, com políticas sanitárias e econômicas que tenham grande impacto social, com adoção efetiva de ações capazes de garantir a sobrevivência das pessoas (e empresas), com a efetiva transferência de renda, o que acarreta o estímulo à demanda nos gastos públicos. Quero, neste artigo, enfatizar que a resposta no âmbito do cuidado (seja do ponto de vista individual, seja institucional) é central diante da vulnerabilidade da vida humana. A defesa da vida, em nosso atual contexto político, enquadra-se na luta contra o autoritarismo crescente, em face do qual duas facetas do cuidado devem vir à luz, a saber, a solidariedade e o espírito de comunidade. O cuidado, como aqui empregado, exigirá repensar a noção filosófica de responsabilidade enquanto uma atitude na qual a pessoa sai de si e visa o outro, com solicitude.

Não abordarei a questão da pandemia pela perspectiva das modificações ambientais, as quais, promovidas pelas ações humanas, nos levaram para a era do antropoceno, nem pelas chamadas éticas do cuidado, identificadas pelo termo care, em inglês, que teve no

\footnotetext{
${ }^{2}$ Até um simples ato de civilidade, como "apertar as mãos", estaria banido das nossas relações sociais nestes dias de pandemia e confinamento, segundo as palavras de Bernard-Henry Lévy (2020, p. 61). Para o crítico francês, passaríamos de um estado de proteção ao de vigilância, teríamos a saúde em lugar da assistência, e reconheceríamos um deslocamento "[...] do antigo contrato social para o novo contrato vital" (id., p. 81). Esse debate entre a perda de liberdade e a defesa da vida (com as medidas sanitárias que lhe são exigidas) agitou o meio intelectual francês, ao longo dos meses de 2020, conferindo à discussão fílosófica um contexto público (DUPUY, 2020).
} 
livro de Carol Gilligan (1982) um estudo propulsor e certamente muito interessante, para essa temática, dentro das discussões de bioética. Trabalhos posteriores a esse estudo, como aquele de Tronto (1993), demarcam uma corrente feminista dentro da bioética, cujo eixo teórico enfatiza a noção de afetividade, sendo formulada pelas exigências de contextualização, de cunho histórico e sociológico. ${ }^{3}$

A noção filosófica de cuidado aqui desenvolvida pertence ao campo ético das relações intersubjetivas, da qual a noção de interesse pelo outro é o resultado de uma atenção que lhe é dirigida. O conceito de cuidado nos coloca em face de dois contextos muito atuais: por um lado, o poder crescente sobre a vida, expresso na tecnologia médica (da qual Hans Jonas é uma voz crítica eloquente), e, por outro, a vulnerabilidade da própria vida humana, que exige de nós um olhar agudo ao outro, à sua condição singular e pessoal, movimento esse bem delineado pela noção de solicitude, desenvolvida no pensamento ético de P. Ricoeur. Há uma assimetria constitutiva, na relação de cuidado, entre a fraqueza que requer ajuda e a capacidade de curar, a qual, no limite, pode se tornar um poder abusivo. Pensar o cuidado no âmbito da relação exige responsabilidade e solicitude, sendo, pois, a expressão ao mesmo tempo da atenção mútua entre os homens e do rigor meticuloso da ação; em outras palavras, é um ligar-se aos outros, individualmente e coletivamente, com a preocupação - e o rigor técnico - para preservar a vida.

No caso da pandemia atual, agir pelo outro, em situação de vulnerabilidade, com as exigências sanitárias adequadas. Nesse sentido, a reflexão filosófica sobre o cuidado não deixará de fazer referência, sempre e de modo sugestivo, ao papel ocupado pela medicina como modelo para se pensar a cura e o equilíbrio de um corpo doente, quer o humano, quer, metaforicamente, o político e o social, como fizeram Platão e Sófócles, na antiguidade. Cabe lembrar que o outro termo do título deste artigo - vulnerabilidade - traz em sua raiz a palavra vulnus (ferida), a qual evoca sofrimento. E, se o sofrimento é uma passividade, a ele está ligada uma vertente ativa, que é a atenção e a receptividade dispensada pelo outro.

\footnotetext{
${ }^{3}$ Ver, a respeito, o verbete "Feminist Bioethics", de A. Donchin e J. Sailly (2015), na Stanford Encyclopedia of Philosophy, de 2015. O dossiê, publicado na revista Esprit, em 2006, coordenado por F. Worms, discute a amplitude do termo cuidado, no âmbito da filosofia e das ciências humanas, mostrando que se trata de um tema extremamente atual e fecundo para a reflexão do momento presente. No mesmo sentido, temos o livro do mesmo Worms, La philosophie du soin. Éthique, medicine et societé. Paris: PUF, 2010. Parte deste artigo é devedor desses estudos.
} 


\section{O CUIDADO ENQUANTO UMA OCUPAÇÃO HUMANA}

O termo cuidado apresenta, na reflexão filosófica e literária, desde a antiguidade clássica, um relevante apreço ético que poderia ser expresso pela inteligência humana que se volta para si mesma, na intenção do autoconhecimento ou, ainda, quando se volta atenciosamente para o outro, seja numa relação convivial, seja mesmo política. É bem conhecida a exortação de Sócrates aos atenienses, para que deixem de lado as riquezas e as questões ligadas à honra e fama pessoal, mesmo que por algum tipo de merecimento, e se dediquem ao cuidado da alma. Vale a pena citar o texto de Platão: "Excelentíssimo homem, sendo de Atenas, da maior e mais bem reputada cidade em saber e poderio, não te envergonhas de cuidar da riqueza, para que seja o quanto maior, da reputação e da honra, ao invés de cuidar e te preocupar com o pensamento, a verdade e a alma, para que seja o quanto melhor?"(PLATÃO, 1982, 29d-e). O cuidado (epimiléia) ${ }^{4}$ aqui enfatizado com relação à alma, diz respeito ao tema do autoconhecimento, ligado com a famosa expressão socrática do "conhece-te a ti mesmo". Mas o cuidado também possui uma dimensão política, como deixa entrever o diálogo Alcebiades, do mesmo Platão: querer ser um conselheiro político (interesse de Alcebíades) exige do postulante o cuidado prévio com a sua alma, a fim de aprender o que significa praticar a boa política. Esclarece Foucault:

Sócrates mostra ao jovem ambicioso que é muito presunçoso de sua parte querer tomar a seu encargo a cidade, dar-lhe conselhos em entrar em rivalidade com os reis de Esparta ou com os soberanos da Pérsia se não aprendeu anteriormente aquilo que é necessário saber para governar: deve, primeiro, ocupar-se de si próprio - e logo, enquanto ainda é jovem, pois com cinquenta anos será demasiado tarde. (FOUCAULT, 2017, p. 57).

É necessário cuidar de si mesmo (epimeléia eautou) e adquirir a soberania sobre si mesmo, para poder governar os outros. A condição primeira para aquele que quer governar

\footnotetext{
${ }^{4}$ São célebres as páginas de Foucault, na sua História da sexualidade 3, acerca do sentido de epimeléia, não só para a filosofia dos antigos, mas para a compreensão de toda ação cuidadosa, pois não se trata apenas de uma "preocupação" (quer de ordem epistêmica, quer política), mas diz respeito "[...] a todo um conjunto de ocupações; trata-se da epimeléia quando se trata de designar as atividades do dono da casa, as tarefas do príncipe que vela pelos seus súditos; os cuidados que se deve ter para com um doente ou para um ferido, ou ainda as obrigações que se prestam aos deuses ou aos mortos. Igualmente, em relação a si mesmo a epimeléia implica um labor." (2017, p. 65).
} 
os outros é que ele se conheça. Em Platão, ainda é possível verificar o alcance político dessa noção de cuidado, quando o vemos relacionar a prática da medicina com a filosofia: na relação entre o médico e o paciente (numa relação de homens livres), encontramos um triplo movimento que leva à cura: no primeiro, o médico é o portador de um saber e o paciente, o portador de uma doença; na segunda, a relação se inverte: o médico é aquele que escuta a narrativa do paciente e considera o doente de um ponto de vista individual e com aquilo que o cerca; na terceira, os papéis se equilibram e ambos, como homens livres e iguais, buscam a cura no diálogo persuasivo. O médico é, nesse sentido, “[...] aquele que trata das enfermidades desde o começo e conforme o curso natural; conversa com o paciente e seus amigos [...] e por meio da persuasão completa a tarefa de devolver-lhe a saúde" (PLATÃO, 1982, 720 d, grifos nossos). Da assimetria inicial resulta o diálogo entre homens livres, com vistas à cura do paciente.

O tema do cuidado ainda deve ser mencionado, dentro da antiguidade grega, pela ótica da tragédia de Sófocles, poeta grego para quem a moral e a medicina são dois campos de grande interesse. É no enredo da trama da peça Filoctetes (409 ac), talvez menos conhecida que Antígona e Édipo, que a ideia do cuidado com o sofrimento alheio vem à tona. Na viagem para Troia, acidentalmente o herói que dá nome à peça é picado no pé por uma serpente, causando-lhe dores lancinantes e um cheiro fétido que exala de sua chaga. Em face da situação, seus companheiros de viagem decidem livrar-se dele, deixando-o na ilha deserta de Lemnos. Após dez anos de isolamento, os gregos ficam sabendo que a única condição de vencer a guerra de Troia é com a entrada Filoctetes no campo de batalha, com seu arco e flechas recebidos do deus Héracles.

É a partir desse ponto que se tem o desenrolar da trama: Odisseu arma um plano para roubar-lhe o arco, a fim de alcançar a desejada vitória. O jovem guerreiro Neoptólemo é instigado por Odisseu a executar o astucioso plano, a partir da ideia de que temos de fazer o que é necessário para obter nossos objetivos, independentemente de sua correção ou não. De fato, o jovem guerreiro se vê no dilema entre seu dever para com as tropas e a lealdade devida ao infeliz herói. A chegada de Neoptólemo à ilha deserta é, para Filoctetes, a esperança da saída do longo exílio em que foi lançado e, naturalmente, da cura de sua enfermidade. Neoptólemo não consegue cumprir o plano de Odisseu, ao ver a situação 
frágil e doentia de Filoctetes, de modo que, com o apoio decisivo de Héracles, conduz o herói à cura e os gregos à vitória.

Poder-se-ia avaliar cada personagem dessa peça, na riquezas de seus detalhes, de sua condição existencial e moral, como o caso do astucioso Odisseu, para quem a mentira se justifica, desde que em vista de um fim maior (a salvação da pátria), ou ainda de sua desumanidade, ao querer roubar o arco e deixar perecer o doente, na ilha. O próprio personagem que dá nome à peça encerra, por exemplo, o tema da velhice e de como o Estado considera aqueles que, humilhados e abandonados à própria sorte, sofrem até o fim de seus dias. Mas é ao jovem guerreiro Neoptólemo que gostaria de fazer menção, ao destacar, seja seu processo de amadurecimento na tomada de uma posição própria, consignada pelo respeito ao outro (e não aquela de embuste e engano), seja na sua atitude de ajuda diante do sofrimento alheio, ao buscar a cura de Filoctetes, com o auxílio de Asclépios. Depois, ambos seguem para a vitória em Troia. J. P. Vernant destaca essa “mutação do herói trágico" como algo único na obra de Sófocles (1977, p. 143).

Todavia, é em função de uma fábula romana (conhecida como fábula de Higino) ${ }^{5}$ que a noção de cuidado ganhou grande destaque no vocabulário filosófico contemporâneo, a partir de Heidegger, que a fez peça central de seu Ser e Tempo, obra maior da filosofia do século XX. A fábula aparece no $\S 42$ dessa obra como explicação ontológica da estrutura existencial do Dasein, de sorte a expressar a ideia de que o cuidado é um a priori existencial, o qual está na raiz do ser humano e lhe pertence "durante todo seu tempo de vida", e tal precedência do cuidado aparece em conexão "do corpo com o espírito". ${ }^{6}$ Os termos da fábula são os seguintes: Cuidado faz com argila um determinado modelo e pede a Júpiter que empreste seu espírito para vivificar a forma que saíra de suas mãos, à qual intenciona dar seu próprio nome. Júpiter não aceita o nome sugerido pelo artesão e, enquanto discutem, surge Terra, a reivindicar que o seu nome seja dado ao modelo criado, já que o mesmo se originou da argila. Diante do impasse entre os três debatedores, eis que

\footnotetext{
${ }^{5}$ Caio Júlio Higino, escravo liberto de César Augusto, escreveu Fábulas ou Genealogias, uma recopilação de histórias e mitos da tradição greco-latina, por volta do ano 47 a.G. Essa fábula, citada na obra de Heidegger, recebe o número $220 \mathrm{e}$.

${ }^{6}$ HEIDEGGER (2012, § 42). O termo alemão utilizado por Heidegger é Sorge, traduzido por "preocupação", na versão brasileira de Fausto Castilho, e como "cuidado", em outras traduções.
} 
surge Saturno, o qual, ao modo de um juiz, resolve a questão: Júpiter receberá o espírito do modelo depois de sua morte, Terra ficará com o corpo; mas, durante a sua vida, enquanto ele viver, deve ficar com Cuidado, visto que este o criou. Quanto ao nome a ser dado, ele se chamará homem, pois foi feito de húmus - terra (HEIDEGGER, 2012, § 42).

Tal fábula apresenta, entre seus personagens, a figura de Júpiter como aquele que oferece o espírito e vida ao homem, e de Terra, referência ao corpo, polaridade que o marcará profundamente. Saturno é o arquétipo do governante sábio, que decide os termos da contenda. A fábula expressa o sentido do cuidado para a vida humana, de um ser personalizado que moldou da argila o homem e que o acompanha, durante toda sua vida. Sabemos que precisamos dele, não apenas ao nascer, mas quando adoecemos ou quando somos acometidos por algo que está acima de nossas forças. Mais do que um componente psicológico, o cuidado descrito por Heidegger demarca a minha presença no mundo e a minha atividade com um outro "eu", um "tu" no horizonte dessa minha atividade. Nessa relação intersubjetiva, a noção de cuidado diz respeito ao "interesse", como se algo captasse a minha atenção: “O cuidado é a face ativa do meu encontro com o outro, ou do encontro com o outro na medida em que este encontro depende de mim. " (RENAUD, 2008, p. 14). Cuidado que merecemos e devemos prestar aos nossos semelhantes. Num excelente estudo sobre a noção de cuidar, Leonardo Boff conclui:

A fábula-mito de Higino nos ensina pela boca do deus Saturno que o cuidado acompanha o ser humano enquanto peregrinar pelo tempo. O cuidado é o caminho histórico-utópico da síntese possível à nossa finitude. Por isso é o ethos fundamental, a chave decifradora do humano e de suas virtualidades. (BOFF, 2014, p. 95).

\section{JONAS E A NOÇÃO DE RESPONSABILIDADE}

A reflexão de Hans Jonas denuncia a insuficiência dos termos que herdamos da tradição filosófica, para exprimir os questionamentos éticos referentes ao progresso tecnológico necessários à vida. Toda ética está necessariamente assentada numa prévia definição do agente humano, pois visa a formular normas para a ação dos homens, visto não poder eximir-se de um pressuposto antropológico; no entanto, nossa era tecnológica mudou qualitativamente a natureza da ação humana, corroendo as premissas antropológicas 
das éticas tradicionais, impondo a nós uma orientação para o âmbito da responsabilidade. ${ }^{7}$ Já não temos, como era o caso da teckne grega, a imutabilidade da ordem cósmica, pano de fundo originário da ação do homem e de suas incursões na natureza. Outrora, todo engenho e poder do homem sempre recaíam sobre uma natureza, que era passiva e submissa à sua ação instrumental: "[...] a vida do homem se desenvolveu entre a permanência e a mudança: a permanencia era a natureza e a mudança, as suas próprias obras.” (JONAS, 2017, p. 27). ${ }^{8}$

Ocorre que, para Jonas, a técnica moderna alterou de tal modo a biosfera que transformou radicalmente aquele pano de fundo seguro e perene, o qual foi a própria condição de possibilidade da ação humana; transformou-o em uma espécie de "megapolis planetária", na qual não existe fronteira entre o mundus humano da cidade civilizada e a natureza virgem. Com efeito, a natureza já não é mais a mesma, nem fora nem dentro de nós. Uma nova prescrição ética deverá, portanto, erigir-se em prol da natureza e não apenas em prol do humano. Jonas considera o quanto é soberano o poder da ciência biomédica, capaz de manipular o patrimônio genético do indivíduo e romper os limites tradicionais da finitude humana. Em face desse quadro, o que Jonas quer mostrar é que essa natureza alterada modifica também a ética e a política. Assim, mais do que a consciência de um apocalipse brusco e total, como foram, de um certo modo, os efeitos das bombas atômicas, é o vislumbre de uma catástrofe gradual, decorrente do avanço tecnológico em progresso, o que nos leva a redefinir as condições do pronunciamento ético, na atualidade.

Temos, por conseguinte, que construir uma relação de responsabilidade com a natureza, pois a presença do ser humano no mundo, que antes era algo inquestionável e sustentava toda ética, se transforma agora numa obrigação: aquela de preservarmos a natureza em sua inteireza. Nesse sentido, impõe-se a necessidade de uma ética prospectiva

\footnotetext{
${ }^{7}$ A noção de responsabilidade é desenvolvida por Jonas, em seu livro O Princípio de Responsabilidade (1974), obra na qual aparece o essencial de sua reflexão ética. Neste artigo, considero o pensamento de Jonas a partir de seu livro Técnica, medicina e ética (1985), pelo fato de ele expressar "a parte aplicada" do princípio de responsabilidade (JONAS, 2013, p. 19), desenvolvida no livro anterior. Dessa forma, segundo as próprias palavras do autor, os artigos reunidos nesse último livro têm o objetivo de passar "[...] do geral para o particular, da teoria para as proximidades da prática." (ibidem). Farei menção também ao ensaio "Tecnologia e responsabilidade: reflexão sobre as novas tarefas da ética" (JONAS, 2017, p. 23-49).

${ }^{8}$ Não fazia sentido falar de responsabilidade humana, no âmbito da natureza (e sim de engenhosidade), pois ela se basta - toma conta de si mesma - e também do homem: "[...] mas na cidade, onde os homens lidam com homens, a engenhosidade deve estar casada com a moralidade." (JONAS, 2017, p. 27).
} 
que tem no conceito de responsabilidade sua melhor expressão. Um "objeto" de uma ordem totalmente diferente, nada menos do que toda a biosfera do planeta, é agora aquilo sobre o que somos responsáveis. Uma biosfera "[...] com toda a sua abundância de espécies, em sua recém revelada vulnerabilidade perante as excessivas intervenções do homem, reivindica sua parcela de respeito que se deve a tudo que é um fim em si mesmo, quer dizer a todos os viventes." (JONAS, 2013, p. 55). A natureza é, "enquanto responsabilidade humana, um novum a ser estudada na teoria ética" (JONAS, 2017, p. 32). E, de sorte a estudá-la, começa por formular um novo imperativo para essa ética da era da técnica, o qual pode ser enunciado nos seguintes termos: “[...] age de modo que os efeitos de sua ação sejam compatíveis com a permanência da vida humana genuína" (2017, p. 38). Esse imperativo diz respeito aos eventuais efeitos do ato com a continuação da ação humana nas épocas futuras; ele "[...] se estende a um futuro real previsível enquanto uma dimensão inacabada de nossa realidade.” (2017, p. 39). Trata-se de um enunciado com uma vocação não-antropocêntrica, que deverá ser entendido no registro do conceito de prudência aristotélica.

Exemplo desse poder manifestado pela ciência atual está na manipulação tecnológica no interior do indivíduo. Nos últimos tempos, as ciências da vida, com toda sua engenharia potencial, invadem a biologia humana e lhe conferem possibilidades práticas de caráter irreversíveis. Constitui um dever do homem, portanto, considerar antecipadamente as respectivas implicações desse novo conhecimento, isto é, entender "[...] a responsabilidade do homem ao futuro da vida na terra, que agora está exposto de maneira indefesa ao mau uso desse poder." (JONAS, 2013, p. 56). O controle biológico do homem, especialmente o controle genético, coloca como nosso primeiro dever ético o que Jonas chama de raciocínio hipotético, isto é, levar em conta as consequências, antes de empreender a própria ação. Essa situação conduz à interrogação metafísica com a qual até então a ética nunca se defrontara: se e por que deve haver uma humanidade, e se deve haver vida em geral ? (2013, p. 57). Colocamo-nos perante uma situação inédita, na história de nossa razão moral: não temos teoria ética capaz de alcançar os produtos da tecnologia quanto mais poder temos, mais fascinados e frágeis nos tornamos, e isso revela a ambivalência da técnica ligada à sua grandeza, desproporcional em seus efeitos: “[...] o que 
é grande e pequeno se determina pela finitude de nosso palco terrestre [...] Não se conhece os exatos valores limites de tolerância para nenhuma das muitas direções nas quais se avança o expansionismo humano" (2013, p. 59).

De fato, trata-se de uma medida preventiva, cujo objetivo é elaborar prognósticos segundo um raciocínio hipotético, de tal maneira que a esfera da previsibilidade é alargada, do imediato para o mediato, da humanidade de hoje para a humanidade futura. Com efeito, o que Jonas está a propor é que comparemos os benefícios em curto prazo com os malefícios em longo prazo, até que possamos concluir que o movimento do conhecimento moderno, chamado de ciência, coloque ou não em risco a dignidade e a capacidade de responsabilização humanas, nesse espaço que o homem assume como sendo seu, isto é, a esfera planetária (OLIVEIRA, 2014, p. 119-120). Nada menos que o futuro indefinido constitui o horizonte relevante de responsabilidade do homem; seu destino não pode ser reduzido a um lançar de dados, no qual o ato de criar é simplesmente pôr-se à deriva na corrente do devir. Aquilo que será depois de nós, isto é, “[...] o mundo de amanhã nos concerne do ponto de vista ético." (JONAS, 2013, p. 66).

O novo imperativo pensado por Jonas, em contraposição a Kant, invoca uma diferente coerência: não mais do ato consigo mesmo, mas dos seus prováveis efeitos com a permanência da intervenção humana em tempos futuros. Dessa forma, Jonas projeta seu imperativo num previsível futuro real, "[...] como dimensão inconclusa e aberta da nossa responsabilidade" (JONAS, 2013, p. 48), acrescentando um horizonte temporal ao cálculo moral (horizonte este ausente em Kant): tem sentido falar em termos do futuro da humanidade, pois estamos diante da possibilidade iminente de sua própria extinção, e é possível também perguntar até que ponto nós podemos permitir amanhã a permissiva sociedade de hoje (2013, p. 69). Assim entendido, o conceito de humanidade jonasiano não subtrai o suporte vital: a humanidade é vida e não apenas razão, por isso, a responsabilidade recai sempre sobre aquilo que é frágil e perecível, inclusive sobre o material e o orgânico, obrigando a ética a ultrapassar o enfoque da consciência privada e no diálogo de consciência, tornando-se uma tarefa pública (BECKERT, 2012, p. 105).

A tecnologia hoje, para além de suas conquistas objetivas, ganha importancia nas discusões éticas, em virtude da posição central que ocupa nos projetos humanos. Ela 
tornou-se o novo ímpeto da espécie humana, seu mais significativo empreendimento. $\mathrm{O}$ máximo controle sobre as coisas e sobre si mesmo é a vocação do homem moderno. Seu incessante empenho inventivo em sua respectiva gestão alimenta sua autoimagem narcísica. Jonas sublinha o fato de esse feedback entre criador e criatura assegurar a crescente ascendência, de um lado, da natureza humana sobre todos os outros, aquele que é determinado pelo orgulho, pelo sucesso, pelo poder. Nessa dinâmica vertiginosa, a expansão de seu poder equivale à retração da concepção que ele tem de si mesmo e de seu ser.

Porque o reino da criação invadiu o espaço da ação fundamental, a realização do conhecimento tecnociencífico deterioriza-se em vaidade ou, quando menos, em automatismos. A manipulação tecnológica condiciona o homem moderno, instrumentalizando o eu individual, de modo que sua identidade se encontre pouco definida. É possível se entrever aqui a repercussão do pensamento de Jonas naquilo que Victória Camps escreveu sobre o conceito de resposabilidade moderna e, nesse contexto, sobre a falta de identidade e compromissos, na atualidade. Quando as identidades pessoais são frágeis, tendem a manter-se apenas as obrigações formais, as quais são, por sua vez, as mais generalizáveis e as mais fáceis de determinar. É assim, por exemplo, que o bom professor será aquele que não falta à aula e é pontual; será bom filho aquele que obedece a seus pais, realizando suas tarefas; será bom político aquele que não cai em corrupções demasiado evidentes e sabe manter seus eleitores a contento. Dessa maneira, estamos diante de uma escassa responsabilidade, um verdadeiro automatismo moral, o qual não requer compromisso nem interpelação, mas tão somente que cada um cumpra apenas aquilo que lhe é exigido, isto é, suas obrigações formais, sem se meter em assuntos que não the concernem, o que implica, é claro, a impossibilidade de se produzir compromissos autênticos (CAMPS, 1993, p. 61-65).

É para tentar romper esse automatismo moral que Jonas propõe uma nova ética da responsabilidade coextensiva ao raio de alcance de nosso poder (OLIVEIRA, 2014, p. 121). Em nome dessa mesma responsabilidade, a nova natureza de nosso agir moral requer uma nova humildade. Jonas toma o cuidado de não referir tal humildade à sua raiz cristã (como expressão de nossa pequenez), mas às nossas capacidades: “[...] devemos temer mais o 
nosso poder do que a nossa impotência." (JONAS, 2017, p. 48). A preservação da natureza humana genuína e íntegra passa, então, pelo delinear daquilo que ela deve ser, ou seja, é preciso perservá-la em sua dignidade, que não é outra coisa senão nossa capacidade de sermos responsáveis (OLIVEIRA, 2015, p. 68). Para deter o empobrecimento das espécies, a contaminação do planeta e prevenir o esgotamento de suas reservas naturais, é mister pensar num novo ideal nos hábitos de consumo: a “[...] frugalidade é exigida com vistas na preservação de nossa morada terrena, sendo, portanto, uma faceta da ética da responsabilidade para o futuro." (JONAS, 2013, p. 77). O que Jonas quer mostrar, com sua ética da responsabilidade, é que a atitude prudente fortalece nossa identidade e, assim, é um dever seu invadir o campo da criação tecnológica a tal ponto, que deverá fazê-lo sob a forma da iniciativa política.

Para Jonas, não é o "eu” e o "tu” que contam, porém, a consciência de que somos forças causais na configuração do mundo e do futuro: a humanidade como tal e o ser humano como espécie têm enorme influência no mundo. Com isso, Jonas reforça seu imperativo e avança para o terreno da política: “[...] somos um todo, independente da ação de cada indivíduo.” (JONAS, 2013, p. 281). Se, por um lado, o poder de cada um de nós em relação à determinação das coisas e ao destino de nosso entorno tem diminuído, em função da enorme massificação da sociedade, por outro lado, o poder do coletivo cresceu, isto é, o poder de certas instâncias, como a indústria (química, farmacêutica), a agricultura, com seus métodos, o moderno urbanismo, as constitui como exemplos que Jonas utiliza, a fim de mostrar que o tipo de obrigações que o princípio de responsabilidade estimula a descobrir é a responsabilidade de atuação de instâncias as quais não são mais as pessoas concretas, contudo, formam nosso edifício político-social. Isso significa, diz ele, que os grandes problemas éticos levantados pela moderna civilização técnica se transformam em uma questão de política coletiva, porque pedem uma resposta da esfera pública e não tanto da esfera privada. As questões morais formuladas nos dias atuais não giram mais em torno do tema: que devo eu fazer para guiar minha vida? Não, ao invés disso, são da seguinte envergadura: que nós podemos fazer - esse "supersujeito coletivo" (JONAS, 2013, p. 283) para que possamos preservar e manter em sua dignidade as futuras possibilidades dos seres humanos, como eu, no mundo? 
O imperativo da ética da responsabilidade de Jonas, formulada como resposta ao novo tipo de ação humana, na era tecnologica, invoca a sua coerência com os seus prováveis efeitos na vida humana futura. Esse novo imperativo não se dirige mais ao indivíduo ou à esfera privada: dirige-se à esfera pública, porque se projeta num previsível futuro real. Hoje, o reino da criação humana invadiu o espaço da ação fundamental, mas esse homem não é nem "eu" nem "tu”, enfatiza Jonas, é o conjunto, é o futuro indefinido (não o contexto restrito no qual ocorre a ação) que constitui o horizonte relevante de responsabilidade. Por isso, as questões colocadas pela ética da responsabilidade devem ser resolvidas em termos práticos, avançando inclusive para o terreno da legislação; devem, portanto, cair sob a alçada das leis com que a cidade global tem de dotar-se, para que possa haver um mundo para as gerações futuras.

Se o reino da ação foi invadido pela técnica, a moralidade tem que invadir o reino da criação técnica, e tem de fazê-lo sob a forma da iniciativa política. Porque a natureza da ação humana foi alterada, a política deve também sê-lo. Daí o porquê de o imperativo jonasiano ultrapassar a noção de indivíduo, obrigando a ética a ultrapassar o enfoque da consciência privada e o diálogo de consciências, e exprimir-se coletivamente.

Quem é, por conseguinte, o agente da ética da responsabilidade, nos termos jonasianos? A imagem do agente é bem diferente daquela tradicional. A especificidade da responsabilidade pelas gerações futuras repousa no fato de a mesma não se assentar na autoria de um ser, não ser gerada pelo agente, que seria seu sujeito de direito. Com Jonas, percebemos que a ética do futuro consiste em nos responsabilizarmos a tal ponto, que nos tornamos autores de algo que não começamos, de algo que nem sequer tem direito ainda. Por mais difícil que seja pensar uma ética a qual tende a abandonar o foro da individualidade, Jonas coloca questionamentos inéditos e importantes, para que possamos repensar a dinâmica da exata correspondênca entre direitos e deveres, na esfera do tipo específico de ação que temos diante de nós, hoje (PÉREZ, 2012, p. 320).

\section{PAUL RICOEUR E O PAPEL DA PHRÔNESIS}

A reflexão de Paul Ricoeur acerca da sabedoria prática acrescenta, a essa nossa discussão, um dado relevante que concerne à capacidade de discernimento do homem nas 
mais difíceis circunstâncias da ação, tendo como meta o cuidado prestado. A atenção dirigida ao outro consubstancia-se na noção de solicitude, que exige do agente um descentramento do "eu", bem como a possibilidade de dirigir sua atenção ao outro. Uma relação na qual a afirmação do homem a partir de si mesmo implica o reconhecimento da contingência e finitude humanas, o que lhe permite dar "testemunho" diretamente a si e indiretamente ao outro. ${ }^{9}$ A reflexão ética de Ricoeur deixa entrever a necessidade de se pensar a relação entre ética e democracia, dever e sentimento. Ante a crise atual, vê-se a urgência de revitalizar a participação individual com a devida responsabilidade que the é exigida. Ricoeur reencontra e reconstrói temas e noções próprias do discurso ético e moral, num itinerário de análise filosófica que pode ser pensado como uma passagem da ética à moral, a qual se consubstanciaria numa abertura à sabedoria prática.

Refaço resumidamente esse itinerário. Inicialmente, Ricoeur define o domínio da ética, que ele chama como o plano da vivência ética, na sua tripla constituição de intenção da vida boa, com e para os outros, em instituições justas. Em primeiro lugar, trata-se da busca por uma "vida feliz"; é a dimensão individual da ética, concebida como estima de si, enquanto amor próprio e avaliação de si, e da conjugação de ambos se tem a origem da prudência, pensada aqui como automedida do agir. De fato, o projeto existencial do homem não abarca apenas o traço desiderativo, mas se dá no meio do processo deliberativo $\mathrm{e}$ optativo: "Ricoeur pretende levar mais longe do que Aristóteles a dimensão avaliativa do homem, estendendo-a ao projeto de vida, ou ao telos da vida ativa, irredutível, para o estagirita, à diversidade de deliberações e decisões particulares que constituem os meios para a ele aceder." (BECKERT, 2012, p. 91). Duas coisas são consideradas como estimáveis, para Ricoeur: a) a capacidade de agir intencionalmente e b) a capacidade de tomar iniciativas. A estima de si, “[...] o momento reflexivo da práxis: é apreciando nossas ações, que apreciamos a nós mesmos como sendo os autores delas e, portanto, como sendo outra coisa do que simples força da natureza ou simples instrumentos." (RICOEUR, 1995, p. 163). A expressão "com e para com os outros" comporta a dimensão interpessoal, aquela do diálogo, entre um eu e um tu, entendido como solicitude (CESAR, 2016, p. 65).

\footnotetext{
${ }^{9}$ O que o leva a dizer que o homem “[...] é a alegria do sim na tristeza do finito." (RICOEUR, 1960, p. 156).
} 
Não se trata aqui de um plano que se justapõe ao primeiro, todavia, que é concomitante com ele, de modo que a formação do caráter de cada um se mostra indissociável da atenção e cuidado prestados ao outro, numa reciprocidade tal, que o eu contém em si o outro e vice-versa: "Estima e solicitude não podem ser vividos e pensados uma sem a outra. Dizer si não é dizer eu. Si implica o outro de si, a fim de que se possa dizer de alguém que estima a si mesmo como um outro." (RICOEUR, 1995, p. 163). É a reciprocidade que se estabelece entre os insubstituíveis. Ricoeur tem em mente aqui o plano da virtude aristotélica da amizade. Por fim, "no seio de instituições justas", é a dimensão institucional do outro, não como um tu, mas como ele, membro da mesma comunidade. Trata-se do exercício da justiça enquanto virtude, conforme formulada no livro V da Ética Nicomaqueia, que exige quer a igualdade, quer a proporcionalidade, isto é, a atenção que é própria e devida a cada um: "[...] seu problema consiste em formar a idéia de uma igualdade que mantenha as inevitáveis desigualdades da sociedade nos quadros da ética: a cada um na proporção de seu mérito, tal é a formula da justiça distributiva, definida como igualdade proporcional." (RICOEUR, 1995, p. 165).

Ora, o âmbito da ética, segundo a concepção de Ricoeur, comporta três estágios: a vida boa, a solicitude e a justiça. Porém, esse modelo pode apresentar dificuldades (limitações) em face de conflitos reais ou de interesse, criando a necessidade de um plano normativo, entenda-se, moral. Para a economia do texto de Ricoeur, não se trata de uma substituição, mas de continuidade, formulada, pois, no interior do modelo deontológico da moral kantiana. Os três modelos do plano ético são agora considerados no domínio da moral.

A busca pela moralidade tem a substituição da estima de si pela autonomia, enquanto capacidade do sujeito moral de legislar universalmente. Trata-se da primeira formulação do imperativo categórico. Como se sabe, a regra formal não diz o que se deve fazer, mas a que critério é preciso submeter as máximas da ação: que elas sejam universalizáveis, válidas para todo homem, em todas as circunstâncias: “[...] o ato avaliativo deixa de dizer respeito ao sujeito real, empenhado em decidir segundo a oportunidade da sua ação num mundo marcado pela contingência, para passar a ter como paradigma uma lei universal válida para todos os sujeitos, independentemente de suas 
particularidades de caráter e das circunstâncias da ação.” (BECKERT, 2012, p. 92). Com o formalismo, ficam de fora, pelo menos nesse momento, o desejo, o prazer e a felicidade.

Essa estratégia de depuração, assevera Ricoeur, leva à ideia de autonomia, de autolegislação. A única lei que uma liberdade pode se dar não é uma regra de ação (o que devo fazer aqui e agora), porém, o imperativo: "age unicamente segundo a máxima que faças com que possas querer, ao mesmo tempo, que ela se torne lei universal." A solicitude do plano ético (o segundo nesse itinerário da análise) é agora substituído pelo sentimento de respeito dirigido a um sujeito moral como pessoa formal, caracterizada por ser sempre fim e nunca meio ou instrumento da ação: é a explicitação do segundo imperativo categórico: "age sempre de tal modo que trates a humanidade na tua própria pessoa e na do outro, não somente com meio, mas sempre também, como fim em si." Ressalta Ricoeur: "Essa ideia da pessoa como fim em si é decisiva: ela equilibra formalismo do primeiro imperativo. Nesse ponto, sem dúvida, pode-se perguntar o que o formalismo acrescenta à solicitude e, em geral, a moral e à ética. Minha resposta é breve: é por causa da violência que se deve passar da ética à moral." (RICOEUR, 1995, p. 166). Com esse segundo imperativo, vem para o primeiro plano a ideia de humanidade, expresso aqui pela regra de ouro: "não faças ao outro o que não queres que te façam".

$\mathrm{O}$ âmbito da justiça deixa de ser aquele formulado enquanto uma virtude aristotélica e passa a ser um princípio único aplicável a todos os casos. A exigência de igualdade entre todos se sobrepõe ao bem de cada um, num intento uniformizador que Ricoeur descobre para além de Kant, no projeto filosófico de John Rawls, do contrato social ideal, de modo a garantir a justiça, no interior da sociedade.

Também esse modelo moral, isto é, da normatividade, apresenta algumas dificuldades: a) funciona universalmente, não levando em conta as particularidades do contexto no qual os conflitos se dão, o que torna muitas vezes injustas as soluções para os mesmos; b) ao combater as violências, torna-se ele mesmo violento, pois não dá azo à expressão da diversidade (de caracteres, de sentimentos, de desejos, de projetos).

Os conflitos nascidos da aplicação das normas à situações concretas levam ao retorno da moral à ética. Passar pela moral, segundo ponto do itinerário analisado por Ricoeur, significa legitimar e ultrapassar a contingência das opções individuais; agora, 
retornar ao juízo ético, uma vez instituídas as normas morais, representa a "interdição de erigir a forma em conteúdo", sendo a superação desses dois obstáculos o objetivo último de uma sabedoria prática (phrônesis) exercida em situação e onde a convicção se sobrepõe, quer à rigidez da norma, quer ao arbitrário do caráter (BECKERT, 2012, p. 93). As palavras de Paul Ricoeur são precisas: “[...] a sabedoria prática consiste em condutas que estejam o mais possível de acordo com a exceção que a solicitude exige, traindo menos possível a regra." (RICOEUR, 1995, p. 171).

A sabedoria prática evocada por P. Ricoeur permite aplicar as normas às situações concretas. No ensaio "Da moral à ética e às éticas", considerado pelo próprio autor como uma "reescrita" de Soi-même comme un autre, a sabedoria prática é definida como

[...] a capacidade de discernir a reta regra, o ortho logos, nas difíceis circunstâncias da ação. $\mathrm{O}$ exercício dessa virtude é inseparável da qualidade pessoal do homem de sabedoria - o phrônimos - o homem atilado. Entre a prudência e as coisas singulares, o elo é estreito. É então, nas éticas aplicadas que a virtude da prudência pode ser submetida à prova da prática. (RICOEUR, 2008, p. 59-60).

Ricoeur propõe que pensemos a phrônesis nas situações da ética aplicada, entendidas como éticas especiais, como é o caso da ética médica, da ética judiciária e da ética ambiental. O exemplo sugestivo da ética médica talvez ajude a explicitar o que tentamos dizer. Face ao sofrimento do paciente, o médico é levado a fazer uma prescrição. Sabemos que, enquanto médico, ele responde às regras morais do código de deontologia médica, às regras administrativas próprias da saúde pública de seu país e, também, às regras do saber biológico de sua especialidade. P. Ricoeur dirá que a prescrição deve ser fruto de uma phrônesis médica, demarcada por regras precisas, mas confrontadas com a realidade particular do paciente. A prescrição, resultado último da ação médica, é o lugar da visibilidade de um traço fundamental da ética, que é aquele da solicitude, que "[...] exige que o socorro seja prestado a toda pessoa em perigo.” (FAESSE, 2008, p. 351). A sabedoria prática será o instrumento privilegiado das decisões "bioéticas", pondo em destaque a impossibilidade de o agente declinar da sua responsabilidade última e transferi-la para qualquer entidade formal (CESAR, 1998, p.68).

Para os historiadores da filosofia antiga, é muito difícil pensar o elo que liga a phrônesis, formulada no livro VI da Ética Nicomaqueia de Aristóteles, com as situações 
médicas às quais estamos sujeitos numa sociedade complexa como a nossa. Mas é o que P. Ricoeur aponta como um desafio para a reflexão ética (CESAR, 2013, p. 67).

Cristina Beckert designa essa sabedoria prática como solicitude crítica, em que o “[...] cuidado acrítico prestado ao outro, em nome exclusivo da sua fragilidade, seria balizado e temperado pelas normas morais vigentes na comunidade, obrigando ao exercício de uma criatividade prática, tendendo a harmonizar a regra e a exceção.” (BECKERT, 2012, p. 93). A sabedoria prática é o modo de enfrentar a clivagem entre a convicção individual e a norma, como bem entrevista já em Antígona, entre a lei divina (representada por Antígona) e a lei humana (protagonizada por Creonte).

No entanto, um passo deve ainda ser dado, a fim de fechar esse itinerário reflexivo proposto por Ricoeur. A reapropriação da noção de phrônesis implica a orientação dessa noção em direção ao outro, uma ênfase sobre o individual, que, nas palavras do filósofo francês, é uma "visée des singuliers". O polo da alteridade é o fato primitivo de sua pétite éthique (FIASSE, 2008, p. 352). Essa nova dimensão da phrônesis como alteridade permite considerá-la como "phrônesis para muitos", na sua dimensão pública. Aquele que decide, ao ouvir pessoas mais competentes e de notório saber, diminui o risco do arbitrário. A frase é recorrente em Ricoeur: "O phrônimos não é um só homem." O plano do conselho e o traço plural do debate precedem a decisão. Ricoeur instala sua reflexão no domínio político, de modo a asseverar que a dimensão política tem sua importância na decisão ética.

\section{CONCLUSÃO: A ESCOLHA PELA VIDA}

O cuidado mobiliza, primeira e essencialmente, a noção de relação com o outro, na atenção que devemos e manifestamos quanto ao outro. Pelo cuidado, na sua versão médica (médico e paciente) ou parental (mãe e filho), há uma dissimetria de origem que se instaura entre aquele que cuida (o qual possui o poder e a competência para fazê-lo) e aquele que é cuidado (reconhecidamente vulnerável). Inicialmente, tem-se que essa ideia de relação envolve o engajamento da responsabilidade, daquele que é o autor efetivo do cuidar. Agir de maneira responsável em relação a si mesmo e em relação aos outros é confirmar uma rede de relações humanas, saber desenvolver uma atividade que responde a uma 
necessidade, a um apelo e pedido de socorro, às situações de precariedade. A reflexão ética sobre o cuidado, a partir da relação de solicitude, reconhece que o horizonte normativo somente pode ser pensado na constituição da pessoa. Assim entendido, diante da pandemia vivenciada nos últimos meses de 2020, e do alto grau de contágio do coronavírus, é preciso cortar as cadeias de transmissão entre os humanos, tomar medidas sanitárias que garantam o isolamento das pessoas, de sorte a diminuir o contágio. Os mais jovens devem solidarizar-se com os mais velhos, nas práticas de cuidado sanitário social, para não colocálos em risco. No debate entre economia e medicina, é falso admitir que uma economia forte e vigorosa seria a melhor saída para o momento em que vivemos, mesmo que se admita (numa lógica perversa) efeitos negativos, como a morte de "algumas" pessoas. Nesse sentido, preservar a economia levaria ao esgotamento do melhor sistema de saúde do mundo. Devemos deslocar nosso olhar para outro tipo de mudança.

Reencontro, nestas palavras finais, os dois poetas da epígrafe, que ainda muito distantes de nós trazem em seus versos o tema da mudança, seja aquela da mutabilidade da vida, seja a de nosso próprio interior, e dos cuidados que devemos guardar diante das incertezas. Sá de Miranda parece sugerir que uma seca prolongada faz da chuva que cai o alívio aos "cuidados graves" dispensados pelo poeta, na sua longa travessia, contudo, nada garante que outros perigos (posteriores) o alcancem e o façam retomar os mesmos cuidados, visto que as coisas são "todas vãs, todas mudaves". Camões também se vê compelido a falar do cuidado e da necessidade da mudança, não sem antes deixar de registrar certa perplexidade, como nos seguintes versos: "E, afora esse mudar-se cada dia/outra mudança faz de mor espanto: que não se muda como soía." A própria forma de mudar sofreu suas modificações: não se muda como estávamos habituados, como se era frequente.

Ora, se as coisas mudam, não podemos simplesmente observá-las pacientemente: nossa ação diante desse novo estado de coisas tem de ser nova, pois, se tudo muda, deve-se mudar o nosso modo de mudar. Se passamos, no plano da natureza, por mudanças tão repentinas (absolutamente novas e catastróficas), será exigido de nós uma mudança em nosso comportamento de hoje, o qual comporte uma relação com o futuro. Mudar não seria reintegrar antigos valores do passado ou preservar a mesmice, como a mudança na fala dos 
políticos, mas ter um cuidado com o futuro, para proteger a nós e ao planeta. Pode-se clamar por um pedido de mudança em favor de uma nova cosmologia (enquanto visão de mudo), uma mudança nos valores, instituições e formas de vida. ${ }^{10}$ Se a mudança na natureza é previsível (o que, para o poeta renascentista, é o simples fato da passagem das estações), a mudança no plano individual é imprevisível, estando associada à nossa percepção da passagem do tempo e da nossa tomada de posição (renovada) diante das coisas. Se não nos restasse explorar nenhum outro planeta, assinala o nosso poeta contemporâneo, caberia a nós humanos a "[...] dificílima dangerosíssisma viagem de si a si mesmo", cujo primeiro passo seria dado no chão de nosso coração, para descobrir a "[...] insuspeitada alegria de conviver." (ANDRADE, 2002). Que esse passo seja dado. Que, por detrás de máscaras que aprendemos a usar, não desapareça a nossa solicitude e que, diante de nós, o outro não fique à espera do nosso cuidado responsável.

\section{Referências bibliográficas}

ANDRADE, C. D. As impurezas do branco. In: ANDRADE, C. D. Poesia Completa. Rio de Janeiro: Nova Aguilar, 2002.

BECKERT, C. Ética. Lisboa: Centro de Filosofia da Universidade de Lisboa, 2012.

BOFF, L. Saber cuidar. Petrópolis: Vozes, 2014.

CAMPS, V. Virtudes Públicas. Madrid: Espasa Calpe, 1993.

CAMÕES, L. V. Sonetos. São Paulo: Ateliê, 2016.

CESAR, C. M. Responsabilidade e cosmos. In: CESAR, C. M. (org.). Paul Ricoeur: Ensaios. São Paulo: Paulus, 1998.

CESAR, C. M. Práxis e Phrónesis em Paul Ricoeur. Ekstasis: Revista de Fenomenologia e Hermenêutica, v. 2, n.1, p. 58-68, 2013.

\footnotetext{
${ }^{10}$ Ao se falar da pandemia e de seus desafios, poder-se-ia pensar aqui em uma cosmologia (ou cosmopolítica, na visão de alguns antropólogos) como aquela descrita pelos yanomamis, através da voz de Davi Kopenawa (2015), na qual o xamã é aquele que não defende somente os habitantes da floresta (homens ou animais), mas aquele que "[...] trabalha para proteger os brancos que vivem em baixo do mesmo céu" (KAPENAWA, 2015, p.492), o qual pode despencar "em nossas cabeças", de modo que "[...] vamos morrer antes mesmo de perceber" (ibidem). Fica dessa cosmologia yanomami a perspectiva de considerarmos a nossa relação com o outro e com a natureza, a partir de um discurso que seja integrador (ecológico, no entendimento do xamã), e não racional (como para o homem branco).
} 
CESAR, C.M. Intencionalidade, alteridade e cuidado em Husserl, Merleau-Ponty e Ricoeur. Ensaios filosóficos, v.13, p. 43-69, 2016.

DONCHIN, A.; SAILLY, J. Feminist Bioethics. In: Stanford Encyclopedia of Philosphy, 2015. Disponível em: plato.stanford.edu. Acesso em: 28 nov. 2020.

DUPUY, J-P. Le virus du sophisme - lettre à André Comte-Sponvill. AOC Media, 04 jun. 2020. Disponível em: aoc.media. Acesso em: 01 dez. 2020.

FIASSE, G. La Phronesis dans l'étique de Paul Ricoeur. In: LORIES, D.; RIZZERIO, L. (dir.). Le jugement pratique autour de la notion de phronèsis. Paris: Vrin, 2008. p. 349-360.

FOUCAULT, M. História da sexualidade. O cuidado de si. Tradução de M.T. da Costa Albuquerque. 17. ed. Rio de Janeiro: Paz e Terra, 2017.

GALBRAITH, J. K. The good society: the human agend. Boston: Hougthon Mifftin, 1996.

GILLIGAN, C. In a different voice. Psychological theory and women's development. Cambridge: Harvard University Press, 1982.

HEIDEGGER, M. Ser e Tempo. Tradução de F. Castilho. São Paulo: Editora Unicamp \& Vozes, 2012.

JONAS, H. Técnica, medicina e ética. Tradução de Jelson R. de Oliveira et alii. São Paulo: Paulus, 2013.

JONAS, H. Tecnologia e responsabilidade: reflexões sobre novas tarefas da ética. In:

JONAS, H. Ensaios Filosóficos. Da crença antiga ao homem contemporâneo. Tradução de Wendell Evangelista S. Lopes. São Paulo: Paulus, 2017.

KOPENAWA, D.; ALBERT, B. A queda do céu. Palavras de um xamã yanomami. Tradução de Beatriz Perrone-Moisés. São Paulo: Companhia das Letras, 2015.

LÉVY, B-H. Ce virus qui rend fou. Paris: Grasset, 2020.

OLIVEIRA, J. Compreender Hans Jonas. São Paulo: Vozes, 2014.

OLIVEIRA, J. Vida. In: OLIVEIRA, J.; MORETTO, G.; SGANZERLA, A. Vida, técnica e responsabilidade. Três ensaios sobre a filsoifa de Hans Jonas. São Paulo: Paulus, 2015.

NOBRE, M. Ponto final. A guerra de Bolsonaro contra a democracia. São Paulo: Todavia, 2020 .

PLATÃo. Apologia de Sócrates. Tradução de Carlos Alberto Nunes. Belém: Editora da Universidade Federal do Pará, 1980 (Série Amazônica, v. V). 
PLATÃO. Leis. Tradução de Carlos Alberto Nunes. Belém: Editora da Universidade Federal do Pará, 1986 (Série Amazônica, v. XII).

PLATÃO. Primeiro e Segundo Alcebíades. 2. ed. Tradução de Carlos Alberto Nunes. Belém: Editora da Universidade Federal do Pará, 2000 (Série Amazônica, v. VIII).

PEREZ, J. L. A questão da ética da responsabilidade - Um itinerário pela contemporaneidade. In: BECKERT, C.; PIRES, M. J.; FERNANDES, S.; ANTUNES, T. (org.). Ética: Teoria e Prática. Lisboa: Centro de Filosofia da Universidade de Lisboa, 2012.

RENAUD, M. Solicitude e vulnerabilidade. In: CARVALHO, A. S. Bioética e vulnerabilidade. Coimbra: Almedina, 2008.

RICOEUR, P. La philosophie de la volonté. Vol. II: La symbolique du mal. Paris: Aubier Montaigne, 1960.

RICOEUR, P. Ética e política. In: RICOEUR, P. Em torno do político. Tradução de M. Perine. São Paulo: Loyola, 1995.

RICOEUR, P. Da moral à ética e às éticas. In: RICOEUR, P. O Justo 2. Tradução de I. C. Benedetti. São Paulo: Martins Fontes, 2008.

RICOEUR, P. O si mesmo como um outro. Tradução de I. C. Benedetti. São Paulo: Martins Fontes, 2014.

SÁ DE MIRANDA, F. Obras completas. Manuel Rodrigues Lapa (editor). Lisboa: Sá da Costa, 1937.

TRONTO, J. Moral Boundaries. A Political Argument for an Ethics of Care. New York: Routledge, 1993.

VERNANT, J. P.; VIDAL-NAQUET, P. O Filoctetes de Sófocles e a afebia. In:

VERNANT, J. P.; VIDAL-NAQUET, P. Mito e tragédia na Grécia Antiga. Tradução de M. C. M. Cavalcanti. São Paulo: Duas Cidades, 1977.

Recebido em: 20/12/2020 | Aprovado em: 25/01/2021 